\title{
Određivanje toksičnosti ksenobiotika u vodi
}

\section{T. Borojević, D. Ašperger i D. Dolar}

Sveučilište u Zagrebu, Fakultet kemijskog inženjerstva i tehnologije,

Marulićev trg 19, 10000 Zagreb

\section{Sažetak}

Cilj ovog istraživanja bio je odrediti toksičnost aktivnih supstancija navedenih na popisu praćenja za tvari za koje je potrebno praćenje diljem Unije u području vodne politike u skladu s europskom Direktivom 2008/105/EZ. To su makrolidni antibiotici, herbicidi, insekticidi, antioksidansi, nesteroidni antireumatici, estrogenski hormoni i sredstva za zaštitu od sunca. Primijenjena je brza i jednostavna bioanalitička metoda određivanja akutne ekotoksičnosti ksenobiotika u vodi bakterijom Vibrio fischeri. Navedena bakterija osjetljiva je na organska onečišćenja, odnosno dolazi do inhibicije rasta bakterije, što se očituje smanjenjem njezine prirodno urođene luminiscencije. U tim eksperimentima mjerila se inhibicija luminiscencije bakterije dodatkom različitih koncentracija otopina ksenobiotika. Mjerenja su pokazala kako svi ksenobiotici, osim 2-etil-heksil-6-metoksicinamata uzrokuju inhibiciju bakterijske kulture, a najtoksičniji je insekticid metiokarb.

\section{Ključne riječi}

Ksenobiotici, toksičnost, voda, Vibrio fischeri

\section{Uvod}

Voda je nužna za život i zbog nemogućnosti života bez nje ključna je zaštita i očuvanje tog "izvora života". Europska unija zato je izdala Okvirnu direktivu o vodama (ODV) koja uspostavlja osnovne principe zaštite voda od zagađenja i onečišćenja. Strategija sprječavanja onečišćenja voda uključuje popis od 45 prioritetnih tvari ili grupa tvari koje predstavljaju značajan rizik za vodni okolišs, a među njih su svrstani i ksenobiotici. Posljedica uporabe ksenobiotika je njihova prisutnost u okolišu gdje zbog različitih fizikalno-kemijskih svojstava podliježu procesima razgradnje, a njihovi produkti često su toksičniji od njih samih. Podatci o toksičnom utjecaju ksenobiotika na čovjeka istraženi su i jasno definirani, ali toksičnost za okoliš nije utvrđena. Najveći razlog tome je nemogućnost potpunog kontroliranja ispuštanja ksenobiotika iz industrije i kućanstava u okoliš, pa je stoga iznimno važno kontinuirano analizirati uzorke vode i utvrditi maksimalno dopuštene količine ksenobiotika u okolišu. ${ }^{1,2}$

\subsection{Ksenobiotici u okolišu}

Ksenobiotici su tvari koje se pojavljuju u okolišu, a koje nisu nastale u njemu i nisu sastavni dio određenog biološkog sustava. Razvijeni su da bi već u malim dozama postigli određene farmakološke učinke na ljude, biljke ili životinje, pa zbog svojih svojstava često uzrokuju nenamjeravane posljedice za živi svijet. Pripadaju grupi mikrozagađivala, budući da su u vodenoj sredini prisutni u mikrogramskim ili nanogramskim koncentracijama. Potrošnja ksenobiotika, a najviše farmaceutika, sve više raste zbog sve veće starosti stanovništva, porasta broja stanovništva, rasta potrošnje i tržišta proizvodnje, istjecanja patenata i novih neistraženih bolesti (slika 1). ${ }^{3,4}$

U radu su ispitani najčešće upotrebljavani makrolidni antibiotici (azitromicin, klaritromicin, eritromicin), herbicidi (trialat, oksadiazon), insekticidi (metiokarb, klotianidin, acetamiprid, tiakloprid, tiametoksam, imidakloprid), antioksidansi (2,6-di-tert-butil-4metilfenol), nesteroidni antireumatici (diklofenak), estrogenski hormoni (estron, etinilestradiol-17 $\alpha$, estradiol$17 \beta)$ i sredstva za zaštitu od sunca (2-etil-heksil-6metoksicinamat) koji se nalaze na popisu za praćenje. ${ }^{2}$

\footnotetext{
*Autor za dopisivanje: Tea Borojević, bacc. appl. chem. e-pošta: tea0310@gmail.com
} 


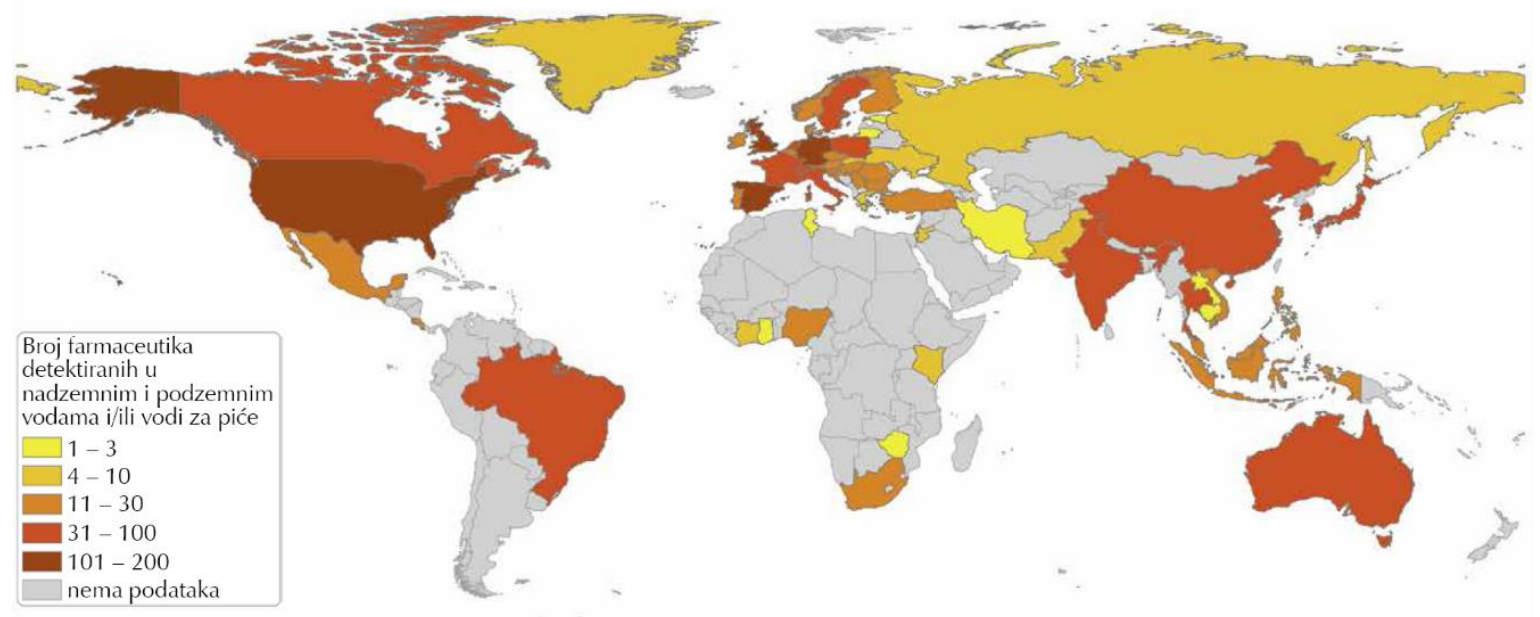

Slika 1 - Farmaceutici u vodi ${ }^{4}$

Fig. 1 - Pharmaceuticals in water ${ }^{4}$

Razumijevanje i mogućnost predviđanja nakupljanja štetnih tvari u okolišu važni su zbog toga jer su učinci tih tvari izravna posljedica njihove koncentracije. lako je koncentracija ksenobiotika u vodenim sustavima niska, kontinuirano ispuštanje može dovesti do bioakumulacije i dugoročnog rizika za vodene, ali i sve druge organizme, stoga se taj problem posljednjih nekoliko godina smatra jednim od prioritetnih problema životne sredine.

\subsection{Toksičnost i iskazivanje toksičnosti}

Ekotoksikologija je grana toksikologije usredotočena na istraživanje toksičnih učinaka nastalih kao posljedica prisutnosti prirodnih ili umjetno stvorenih štetnih tvari (zagađivala) na ljude, životinje, biljke, mikroorganizme i sve ostale sastavne dijelove ekosustava. Štetna tvar je tvar štetna za ljudsko zdravlje ili okoliš, s dokazanim akutnim i kroničnim toksičnim učincima, vrlo nadražujuća, kancerogena, mutagena, nagrizajuća, zapaljiva i eksplozivna tvar, ili tvar koja u određenoj dozi i/ili koncentraciji ima takva svojstva. Akutna izloženost je jednokratni unos otrova u organizam, odnosno svaka izloženost kroz jedan dan ili kraće vrijeme. U ovom radu ispitivana je akutna toksičnost ksenobiotika. Toksičnost se najčešće iskazuje kraticama doza ili koncentracija koje uzrokuju štetno djelovanje određenog postotka populacije. $^{5}$

\subsection{Bioluminiscentna metoda - DIN 38412-L34}

Određivanje biološke toksičnosti pomoću luminiscencije bakterija opisano je u DIN-ovim standardima. Za određivanje toksičnosti $\mathrm{u}$ ovom je radu primijenjena njemačka standardna metoda DIN 38 412-L34. To je praktična bioluminiscentna metoda koja spada među testove kratkog trajanja, jer traje samo 30 min. Kao testni organizam upotrijebljena je fluorescentna bakterija Vibrio fischeri. ${ }^{6}$

\subsection{Vibrio fischeri}

Vibrio fischeri je bioluminiscentna, gram-negativna bakterija u obliku štapića pronađena pretežito u morskim sredinama. Bioindikator Vibrio fischeri, emitira svjetlost ujednačenog intenziteta, danju i noću, kao normalni sastavni dio svojeg metabolizma. Mjerenjem intenziteta emitirane svjetlosti moguće je utvrditi svako oštećenje bakterijskog metabolizma nastalog uslijed djelovanja toksične tvari. Bakterija je ključni istraživački organizam za ispitivanje mikrobiološke bioluminiscencije, kvorskog senzora i simbioze bakterija i životinja. Morska bakterija Vibrio fischeri najbolje je poznata kao specifični simbiont u svjetlosnim organima određenih liganja (slika 2).6,7

\section{Eksperimentalni dio}

U ovom radu bilo je potrebno izmjeriti početne luminiscencije bakterijske suspenzije, $\mathrm{u}$ te otopine pipetirati otopinu ksenobiotika i mjeriti luminiscenciju nakon određenog vremena inkubacije, u ovom slučaju $30 \mathrm{~min}$ 


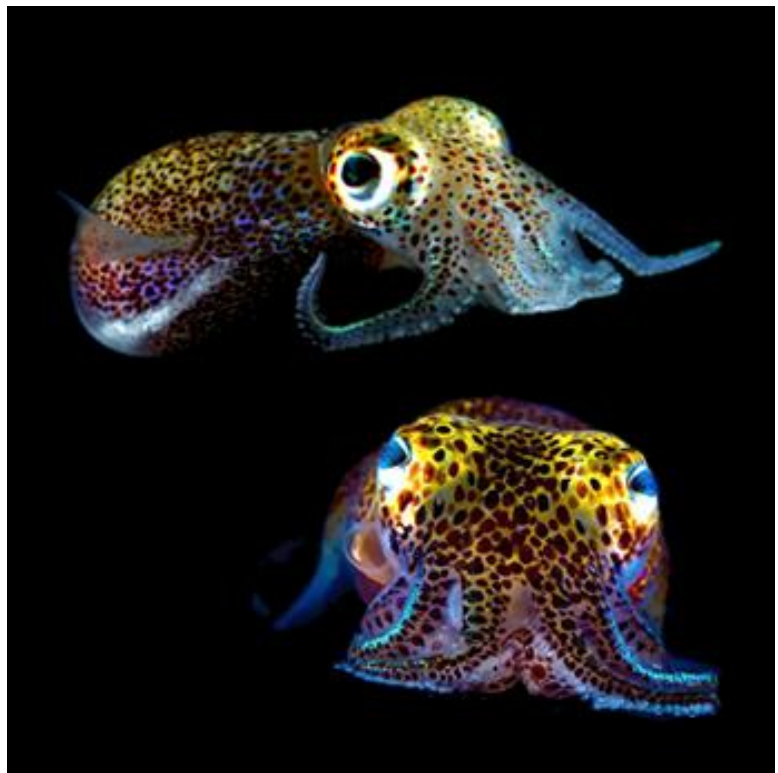

Slika 2 - Lignja Euprymna scolopes s bakterijom Vibrio fischeri ${ }^{8}$

Fig. 2 - Euprymna scolopes squid with the Vibrio fischeri bacteria ${ }^{8}$

Nakon toga se iz razlike početne i konačne luminiscencije računa postotak inhibirane kulture (I) u navedenih $30 \mathrm{~min}$, što ujedno i predstavlja os ordinatu na grafu toksičnosti otopine određenog ksenobiotika, dok je na apcisi logaritam koncentracije otopine ksenobiotika. Iz grafa se kasnije očitaju vrijednosti $E C_{20}$ i $E C_{50}$, masene koncentracije koje uzrokuju $20 \%$, odnosno $50 \%$ inhibicije bakterijske kulture. Također, očita se i LOEC (najniža koncentracija koja izaziva vidljivi štetni učinak) za svako mjerenje ksenobiotika kako bi se lakše usporedilo dobivene podatke o toksičnosti. ${ }^{6}$

Iz očitane $E C_{50}$ vrijednosti izračuna se TU (eng. toxicity unit) prema jedn. (1): ${ }^{9}$

$$
T U=100 \cdot\left(E C_{50}\right)^{-1}
$$

\subsection{Ispitivani ksenobiotici}

U ovom radu upotrijebljeni su ksenobiotici čistoće $>99 \%$ proizvođača Sigma-Aldrich. Temeljne standardne otopine ksenobiotika masene koncentracije $200 \mathrm{mgl}^{-1}$ pripremile su se otapanjem $2 \mathrm{mg}$ ksenobiotika u metanolu HPLC čistoće u tikvicama od $10 \mathrm{ml}$.

Radne otopine od $100 \mathrm{mgl}^{-1}$ pripremile su se $\mathrm{u}$ redeioniziranoj vodi u tikvicama od $10 \mathrm{ml}$.

Tablica 1 - Svojstva ispitivanih ksenobiotika ${ }^{10}$

Table 1 - The properties of the examined xenobiotics ${ }^{10}$

\begin{tabular}{lccccc}
\hline Ksenobiotik & Kemijska formula & CAS broj & Molekulska masa & log $K_{\text {ow }}$ \\
\hline azitromicin & $\mathrm{C}_{38} \mathrm{H}_{72} \mathrm{~N}_{2} \mathrm{O}_{12}$ & $83905-01-5$ & 748,99 & 4,02 \\
eritromicin & $\mathrm{C}_{37} \mathrm{H}_{67} \mathrm{NO}_{13}$ & $114-07-8$ & 733,94 & 3,06 \\
klaritromicin & $\mathrm{C}_{38} \mathrm{H}_{69} \mathrm{NO}_{13}$ & $81103-11-9$ & 747,96 & 3,16 \\
imidakloprid & $\mathrm{C}_{9} \mathrm{H}_{10} \mathrm{ClN}_{5} \mathrm{O}_{2}$ & $105827-78-9$ & 255,66 & 0,57 \\
tiakloprid & $\mathrm{C}_{10} \mathrm{H}_{9} \mathrm{ClN}_{4} \mathrm{~S}$ & $111988-49-9$ & 252,72 & 1,26 \\
klotianidin & $\mathrm{C}_{6} \mathrm{H}_{8} \mathrm{ClN}_{5} \mathrm{O}_{2} \mathrm{~S}$ & $210880-92-5$ & 249,67 & 0,70 \\
acetamiprid & $\mathrm{C}_{10} \mathrm{H}_{11} \mathrm{ClN}_{4}$ & $135410-20-7$ & 222,68 & 0,80 \\
tiametoksam & $\mathrm{C}_{8} \mathrm{H}_{10} \mathrm{ClN}_{5} \mathrm{O}_{3} \mathrm{~S}$ & $153719-23-4$ & 291,71 & $-0,13$ \\
metiokarb & $\mathrm{C}_{11} \mathrm{H}_{15} \mathrm{NO}_{2} \mathrm{~S}$ & $2032-65-7$ & 225,31 & 2,92 \\
oksadiazon & $\mathrm{C}_{15} \mathrm{H}_{18} \mathrm{Cl}_{2} \mathrm{~N}_{2} \mathrm{O}_{3}$ & $19666-30-9$ & 345,22 & 4,80 \\
tri-alat & $\mathrm{C}_{10} \mathrm{H}_{16} \mathrm{Cl}_{3} \mathrm{NOS} \mathrm{OS}$ & $2303-17-5$ & 304,65 & 4,60 \\
etinilestradiol-17 $\alpha$ & $\mathrm{C}_{20} \mathrm{H}_{24} \mathrm{O}_{2}$ & $57-63-6$ & 296,41 & 3,67 \\
estradiol-17 $\beta$ & $\mathrm{C}_{18} \mathrm{H}_{24} \mathrm{O}_{2}$ & $50-28-2$ & 272,39 & 4,01 \\
estron & $\mathrm{C}_{18} \mathrm{H}_{22} \mathrm{O}_{2}$ & $53-16-7$ & 270,37 & 3,13 \\
diklofenak & $\mathrm{C}_{14} \mathrm{H}_{11} \mathrm{Cl}_{2} \mathrm{NO}_{2}$ & $15307-86-5$ & 296,15 & 4,51 \\
2,6-di-tert-butil-4-metilfenol & $\mathrm{C}_{15} \mathrm{H}_{24} \mathrm{O}$ & $128-37-0$ & 220,36 & 5,10 \\
2-etil-heksil-4-metoksicinamat & $\mathrm{C}_{18} \mathrm{H}_{26} \mathrm{O}_{3}$ & $5466-77-3$ & 290,40 & 6,10 \\
\hline
\end{tabular}




\subsection{Instrument za mjerenje toksičnosti}

Za mjerenje toksičnosti upotrijebljen je instrument LUMIStox 300 (slika 3). LUMIStox 300 je mjerni instrument razvijen za mjerenje luminiscencije (jačine svjetlosti) luminiscentnih bakterija i primjenjuje se zajedno s termostatskim blokom LUMIStherm za inkubaciju bakterija.

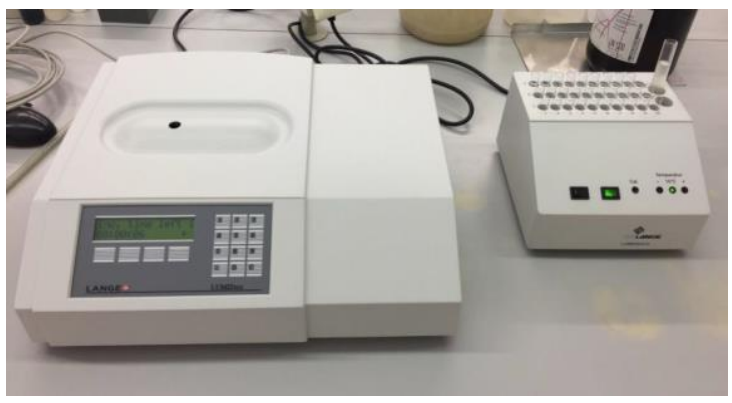

Slika 3 - Instrument za mjerenje toksičnosti

Fig. 3 - Instrument for measuring toxicity

\subsection{Rad s bakterijama Vibrio fischeri}

Primjenjuje se sterilna tehnika rada koja uključuje rad uz upaljeni plamenik na površini dezinficiranoj etanolom (antiseptikom). Plamenik mora biti upaljen na oksidirajućem plamenu. Eza koja se upotrebljava mora se najprije spaliti u unutarnjem plamenu, a zatim cijelom duljinom zažariti u vanjskom dijelu plamena.

Da bi se aktivirala kultura, kiveta s liofiliziranim bakterijama izvadi se iz zamrzivača i u nju se odmah ulije $1-2 \mathrm{ml}$ otopine za reaktivaciju. Priređena suspenzija se termostatira 15 min pri $15^{\circ} \mathrm{C}$ kako bi se kultura adaptirala. Luminiscencija nakon adaptacije mora biti veća od 1000. Takva suspenzija izlije se na sterilnu hranjivu podlogu (tablica 2) i razvuče sterilnom ezom po podlozi cik-cak pokretima. Kultura se održava u Petrijevim zdjelicama pri temperaturi $15-22{ }^{\circ} \mathrm{C}$.

Tablica 2 - Sastav hranjive podloge $\mathrm{e}^{11}$

Table 2 - Composition of nutrient base ${ }^{11}$

\begin{tabular}{lc}
\hline Sastojci & u $1000 \mathrm{ml}$ \\
\hline $\mathrm{NaCl}$ & $30 \mathrm{~g}$ \\
agar & $15 \mathrm{~g}$ \\
glicerol & $10 \mathrm{~g}$ \\
pepton & $5 \mathrm{~g}$ \\
kvaščev ekstrakt & $5 \mathrm{~g}$ \\
$\mathrm{CaCO}_{3}$ & $3 \mathrm{~g}$ \\
\hline
\end{tabular}

Bakterijska suspenzija (inokulum) za mjerenje priprema se tako da se epruveta s čepom napuni do $2 / 3$ otopinom za resuspenziju (tablica 3). Ušicom eze zahvati se grudica čiste kulture povlačenjem $u$ duljini od oko $1 \mathrm{~cm}$ te se resuspendira u pripremljenoj epruveti. Ostavi se pola sata u termostatu pri $15{ }^{\circ} \mathrm{C}$, kako bi se bakterijska kultura adaptirala.

Tablica 3 - Sastav otopine za resuspenziju ${ }^{11}$

Table 3 - Composition of resuspension solution ${ }^{11}$

\begin{tabular}{l|c}
\hline Sastojci & $\mathrm{u} 1000 \mathrm{ml}$ \\
\hline $\mathrm{NaCl}$ & $36 \mathrm{~g}$ \\
$\mathrm{KH}_{2} \mathrm{PO}_{4}$ & $0,2 \mathrm{~g}$ \\
$\mathrm{CaCl}_{2}$ & $0,5 \mathrm{~g}$ \\
$\mathrm{MgSO}_{4}$ & $0,2 \mathrm{~g}$ \\
glicerol & $0,5 \mathrm{ml}$ \\
glukoza & $10 \mathrm{~g}$ \\
rafinoza & $10 \mathrm{~g}$ \\
\hline
\end{tabular}

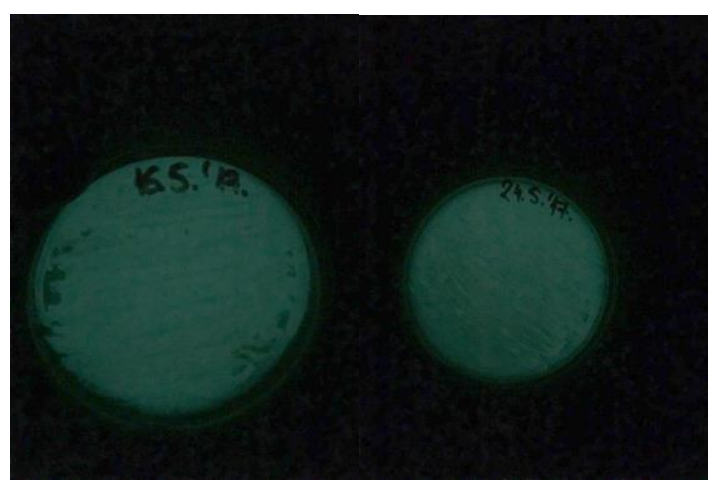

Slika 4 - Luminiscentna bakterija Vibrio fischeri stara 24 sata Fig. 4 -24-hour-old Vibrio fischeri luminiscent bacteria

\subsection{Mjerenje toksičnosti}

Test valjanosti bakterijske kulture izvodi se prije postavljanja mjerenja. $U$ referentnu kivetu stavi se $0,5 \mathrm{ml}$ otopine $2 \% \mathrm{NaCl}$ i $0,5 \mathrm{ml}$ inokuluma. $U$ testnu kivetu stavi se $0,5 \mathrm{ml}$ otopine $\mathrm{ZnSO}_{4} \cdot 7 \mathrm{H}_{2} \mathrm{O}$ i $0,5 \mathrm{ml}$ inokuluma. Ostavi se na termostatu 15 min te se na LUMIStox uređaju pokrene SCRN program. Očita se vrijednost. Sadržaj testne kivete u odnosu na sadržaj referentne kivete mora imati između $20 \%$ i $80 \%$ luminiscencije. U prvu kivetu stavi se $2 / 3$ kivete $2 \% \mathrm{NaCl}$, a u zadnju 2/3 radne otopine uzorka. U sve ostale kivete stavi se po $1,5 \mathrm{ml} 2 \% \mathrm{NaCl}$. Pripremi se geometrijski niz razrjeđenja prema prikazu na slici 5 . 


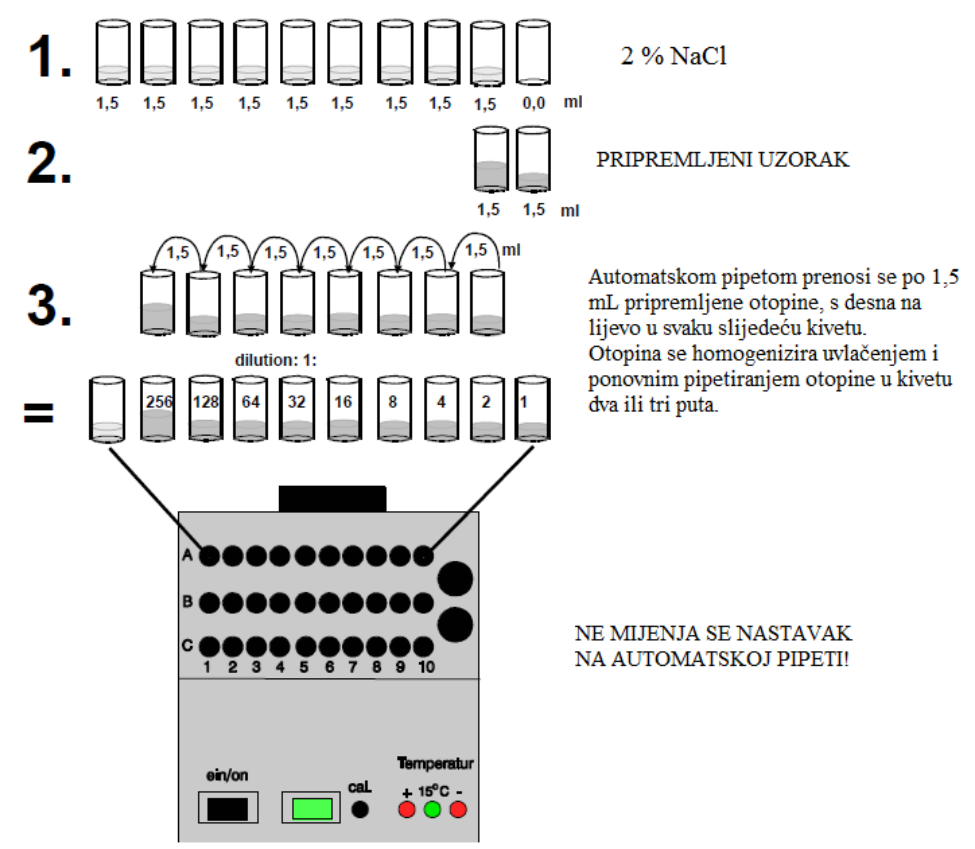

Radna otopina za resuspenziju, $2 \% \mathrm{NaCl}$ uvijek se nalazi u A1. Uzorak najviše koncentracije, u ovom slučaju nerazrijeđene otopine, nalazi se krajnje desno, A10.

Slika 5 - Priprema geometrijskog niza razrjeđenja ${ }^{6}$

Fig. 5 - Preparation of the geometric dilutions series ${ }^{6}$

Na uređaju LUMIStox 300 odabire se program EC i postave se propisani uvjeti. Nakon očitavanja prve kivete B1 na luminometar se stavlja druga $\mathrm{C} 1$, a iz kivete $\mathrm{A} 1 \mathrm{u}$ kivetu B1 pipetira se $0,5 \mathrm{ml}$ otopine. Nakon očitavanja kivete $\mathrm{C} 1 \mathrm{na}$ luminometar se stavlja kiveta B2, a u C1 se pipetira $0,5 \mathrm{ml}$ otopine iz A1. I tako za svaki uzorak do kraja mjerenja. Rezultati se očitavaju i odmah zapisuju za izmjereni uzorak prije promjene kivete i prije pipetiranja iz reda A (slika 6). Nakon 30 min ponovno se izmjeri luminiscencija svih uzoraka. ${ }^{6}$

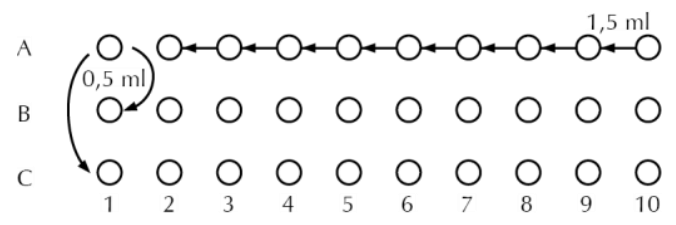

Slika 6 - Princip mjerenja toksičnosti ${ }^{11}$

Fig. 6 - Principle of toxicity measurement ${ }^{11}$

\section{Rezultati i rasprava}

Dobiveni rezultati prikazuju se grafički i tablično. Os ordinatu na grafu toksičnosti otopine određenog ksenobiotika predstavlja I, dok je na apcisi logaritam masene koncentracije otopine ksenobiotika. Grafički su prikazane krivulje toksičnosti za oba mjerenja pojedinog ksenobiotika. Tablično su prikazani očitani i izračunati parametri toksičnosti te standardno odstupanje između dva mjerenja.

Za jednostavniju interpretaciju ukupnih rezultata eksperimenta svi izmjereni i izračunati parametri prikazani su u tablici 5. S obzirom na to da ne postoje literaturni podatci za toksičnost mjerenih ksenobiotika u odnosu na Vibrio fischeri u tim uvjetima, rezultati se mogu uspoređivati međusobno i unutar određene skupine. Za analizu dobivenih rezultata zbog jednostavnosti je primijenjena vrijednost $T U$. Iz skupine makrolidnih antibiotika obrađeni su azitromicin, eritromicin i klaritromicin. Najveću toksičnost među njima pokazuje klaritromicin $(T U=4,37)$, a najmanju azitromicin $(T U=1,85)$. Analizirani su najvažniji predstavnici neonikotinoida - klotianidin, tiakloprid, imidakloprid, acetamiprid i tiametoksam. Najveću toksičnost pokazao je 
acetamiprid ( $T U=4,30)$, najmanju tiakloprid $(T U=1,95)$. Od herbicida u ovom su radu analizirani oksadiazon i trialat. Trialat je pokazao veću toksičnost od oksadiazona.
Diklofenak je jedan od najkorištenijih nesteroidnih antireumatika i često se ispušta u okoliš.

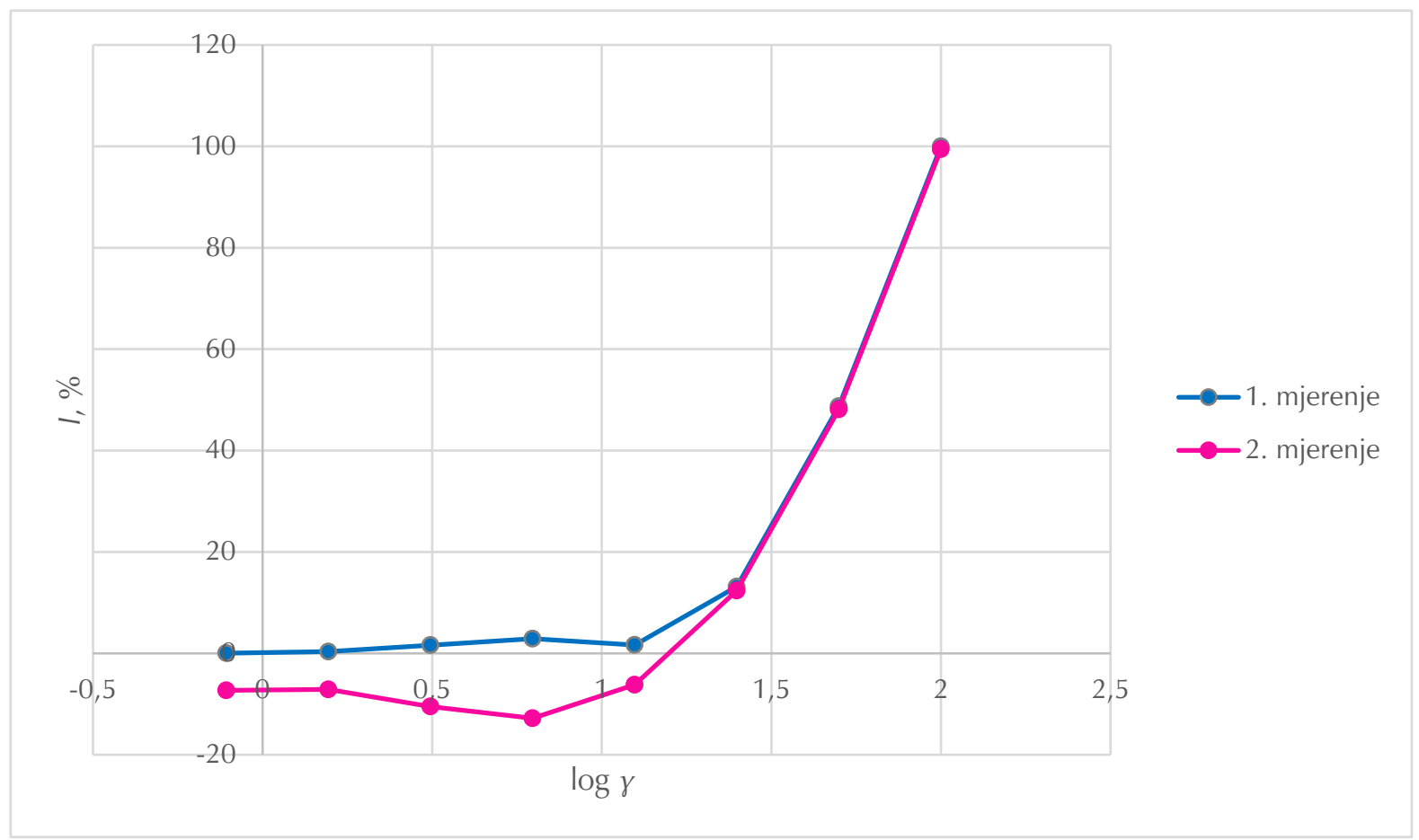

Slika 7 - Grafički prikaz rezultata mjerenja toksičnosti

Fig. 7 - Graphic display of toxicity measurement results

Tablica 4 - Očitane vrijednosti $E C_{20}, E C_{50}, L O E C$ s pripadajućom I te izračunata $T U$ za otopinu tiakloprida Table 4 - Measured parameters $E C_{20}, E C_{50}$, $L O E C$ with belonging I, and calculated $T U$ for thiacloprid solution

\begin{tabular}{l|c|c|c|c|c}
\hline \multirow{2}{*}{ Farmaceutik } & \multicolumn{5}{|c}{ Tiakloprid } \\
\cline { 2 - 6 } & $E C_{20} / \mathrm{mgl}^{-1}$ & $E C_{50} / \mathrm{mgl}^{-1}$ & $T U$ & $L O E C / \mathrm{mgl}^{-1}$ & $I / \%$ \\
\hline 1. mjerenje & 28,184 & 51,286 & 1,95 & 0,781 & 0,04 \\
2. mjerenje & 28,184 & 51,286 & 1,95 & 25 & 48,12 \\
RSD $/ \%$ & 0 & 0 & & - & \\
\hline
\end{tabular}

Njegova toksičnost slična je vrijednostima većine ksenobiotika mjerenih u ovom radu $(T U=4,30)$. Od estrogenskih supstancija u ovom radu mjereni su estradiol$17 \beta$, estron i etinilestradiol-17 $\alpha$. 2,6-etil-heksil-4- metoksicinamat jedini je ispitivani spoj koji nije toksičan jer ne dolazi do smanjena inhibicije, već do njezina rasta, dok je metiokarb najtoksičniji ksenobiotik po svim parametrima jer pri najmanjim masenim koncentracijama uzrokuje inhibiciju bakterijske kulture. 
Tablica 5 - Izmjereni parametri toksičnosti: $E C_{20}, E C_{50}, L O E C$ s pripadajućom I, te izračunata $T U$ Table 5 - Measured toxicity parameters: $E C_{20}, E C_{50}, L O E C$ with belonging I, and calculated TU

\begin{tabular}{|c|c|c|c|c|c|}
\hline Ksenobiotik & $E C_{20} / \mathrm{mgl}^{-1}$ & $E C_{50} / \mathrm{mgl}^{-1}$ & $T U$ & $L O E C / \mathrm{mgl}^{-1}$ & $1 / \%$ \\
\hline azitromicin & 47,361 & 58,580 & 1,85 & 75,000 & 79,51 \\
\hline eritromicin & 28,880 & 44,710 & 2,52 & 31,250 & 22,75 \\
\hline klaritromicin & 13,221 & 23,040 & 4,37 & 9,375 & 2,00 \\
\hline klotianidin & 21,451 & 30,052 & 3,38 & 25,000 & 32,64 \\
\hline tiakloprid & 28,184 & 51,286 & 1,95 & 12,890 & 24,08 \\
\hline imidakloprid & 18,868 & 31,623 & 3,16 & 18,750 & 19,38 \\
\hline acetamiprid & 4,230 & 25,640 & 4,30 & 0,781 & 6,78 \\
\hline tiametoksam & 24,378 & 34,489 & 2,90 & 12,890 & 13,10 \\
\hline metiokarb & 0,928 & 2,147 & 48,03 & 0,781 & 23,94 \\
\hline oksadiazon & 32,668 & 39,280 & 2,55 & 37,500 & 35,87 \\
\hline trialat & 31,442 & 41,454 & 4,83 & 0,781 & 0,03 \\
\hline diklofenak & 9,503 & 25,640 & 4,30 & 0,781 & 3,62 \\
\hline $\begin{array}{l}\text { 2,6-di-tert-butil-4- } \\
\text { metilfenol }\end{array}$ & 14,969 & 21,761 & 4,60 & 12,500 & 7,22 \\
\hline estradiol- $17 \beta$ & 15,637 & 23,753 & 4,23 & 12,500 & 1,083 \\
\hline estron & 15,405 & 23,753 & 4,23 & 12,890 & 28,58 \\
\hline etinilestradiol- $17 \alpha$ & 28,184 & 35,481 & 2,82 & 25,000 & 3,74 \\
\hline $\begin{array}{l}\text { 2-etil-heksil-4- } \\
\text { metoksicinamat }\end{array}$ & - & - & - & - & - \\
\hline
\end{tabular}

\section{Zaključak}

Svi ksenobiotici mjereni su dva puta, no s obzirom na to da se radi o živim organizmima, mjerenja bi se trebala ponoviti i više od dva puta kako bi se pojedino mjerenje moglo odbaciti i kako bi se smanjila pogreška između mjerenja. Najveću toksičnost kod makrolida pokazuje klaritromicin, a najmanju azitromicin, što je pozitivno jer je azitromicin jedna od najkorištenijih aktivnih tvari u proizvodnji lijekova u svijetu. Najveću toksičnost kod neonikotinoida ima acetamiprid, relativno novi insekticid iz skupine, još neistraženih štetnih učinaka na okoliš, a najmanju tiakloprid. Najmanju toksičnost kod hormona pokazuje polusintetski derivat estradiola-17 $\beta$, etinilestradiol- $17 \alpha$, što potvrđuje i razloge primarne sinteze tog hormona, smanjenje toksičnosti estrogenih supstancija koje su jedna od skupina farmaceutika koja se najviše ispušta u okoliš. Izmjeren je samo jedan predstavnik karbamatnih pesticida, metiokarb, i pokazao je veću toksičnost od svih ostalih ksenobiotika i daleko je najtoksičniji ksenobiotik obrađen $\mathrm{u}$ ovom radu iako je i ranije navedeno da je vrlo toksičan za vodene organizme. 2,6-etil-heksil-4-metoksicinamat jedini je ispitivani spoj koji nije pokazao toksičnost, što je pozitivno jer je on aktivni sastojak krema za sunčanje koje su jedan od najkorištenijih proizvoda za osobnu njegu.

Podatci iz ovog rada mogu biti korisni za određivanje maksimalne dopuštene koncentracije u vodi, kao i pomoći u analizi realnih uzoraka ispitivanih spojeva iz okoliša, s obzirom na to da su mjerene otopine čistih aktivnih tvari.

\section{ZAHVALA}

Ovaj rad dio je iz istraživanja sadržanog u završnom radu "Određivanje toksičnosti farmaceutika u okolišu" pod mentorstvom izv. prof. dr. sc. Danijele Ašperger. Ovaj rad financiran je (1.492.908,72 HRK) u sklopu Programa Vlade Republike Hrvatske za poticanje istraživačkih i razvojnih aktivnosti u području klimatskih promjena za razdoblje od 2015. do 2016. godine uz podršku Ministarstva znanosti i obrazovanja, Ministarstva zaštite okoliša i energetike, Fonda za zaštitu okoliša i energetsku učinkovitost te Hrvatske zaklade za znanost, u sklopu projekta Izravna oporaba komunalne otpadne vode za navodnjavanje membranskim tehnologijama (ReHOHMem) (PKP-201606-8522). 


\section{Popis kratica i simbola}

\section{List of abbreviations and symbols}

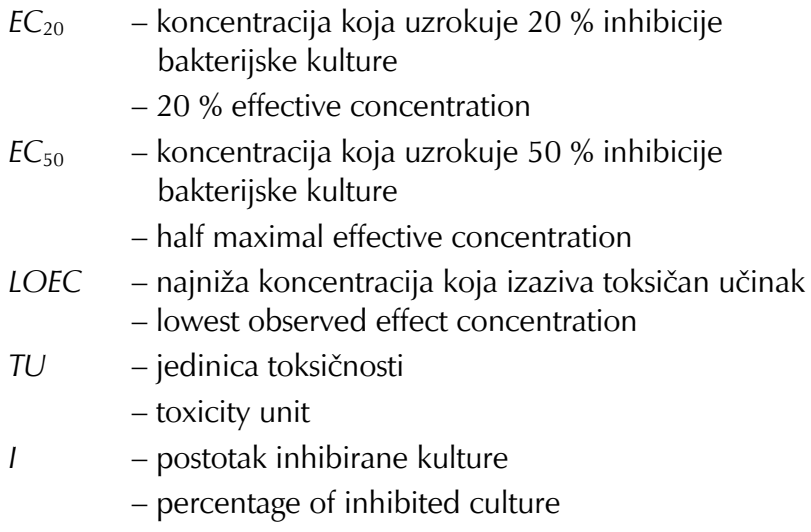

\section{Literatura \\ References}

1. Okvirna direktiva o vodama, http://www.voda.hr/hr/okvirnadirektiva-o-vodama

2. K. Vella, Provedbena odluka komisije (EU) 2015/495 od 20. ožujka 2015. o utvrđivanju popisa praćenja za tvari za koje je potrebno praćenje diljem Unije u području vodne politike u skladu s Direktivom 2008/105/EZ Europskog parlamenta i Vijeća, Bruxelles, 2015.

3. D. Mansuy, Metabolism of xenobiotics: beneficial and adverse effects, Biol. Aujourdhui 207 (2013) 33-37, doi: https://doi.org/10.1051/jbio/2013003.

4. S. Zrnčević, Farmaceutici i metode obrade otpadne vode iz farmaceutske industriji, Hrvatske vode 96 (2016) 119-136.

5. L. Foglar, "Ekotoksikologija", Skripta za studente, https://www.fkit.unizg.hr/_download/repository/Ekotoksikolo gija_SKRIPTA_LF\%5B1\%5D.pdf

6. Dr. Bruno Lange GmbH, LUMIStox 300 Operating Manual, Germany, 1999.

7. M. Korlević, Detaljna analiza bakterijske raznolikosti Jadranskog mora, Doktorski rad, Prirodoslovno-matematički fakultet, Zagreb, 2015.

8. Vibrio fischeri, http://www.microbiologynutsandbolts.co.uk/the-bugblog/why-did-rudolphs-nose-shine-so-bright

9. Jedinica toksičnosti, https://dnr.wi.gov/topic/wastewater/documents/Chap2×4LCI CTU.pdf

10. Svojstva ksenobiotika, https://pubchem.ncbi.nlm.nih.gov

11. J. Papac, Biorazgradnja antiparazitika u vodi, Diplomski rad, Fakultet kemijskog inženjerstva i tehnologije, Zagreb, 2017.

\section{SUMMARY}

\section{Toxicity Determination of Xenobiotics in Water}

\section{Tea Borojević, Danijela Ašperger, and Davor Dolar}

The aim of this research was to determine the toxicity of the active substances listed in the watch lists for substances that need monitoring across the EU in the field of water policy according to European Directive 2008/105/EC. Those are macrolide antibiotics, herbicides, insecticides, antioxidants, nonsteroidal antireumatics, estrogen hormones, and sunscreening agents. A quick and simple bioanalytic method was used to determine the acute ecotoxicity of xenobiotics in water by the Vibrio fischeri bacteria. These bacteria are susceptible to organic contamination, bacterial growth is inhibited, which is manifested by a reduction in their inborn luminescence. In these experiments, inhibition of bacterial luminescence was measured by adding different concentrations of xenobiotic solutions. Measurements have shown that all xenobiotics, except 2-ethylhexyl-6-methoxycinnamate, cause bacterial culture inhibition, and the most toxic xenobiotic is an insecticide, methiocarb.

\section{Keywords}

Xenobiotics, toxicity, water, Vibrio fischeri

University of Zagreb

Faculty of Chemical Engineering and Technology

Received April 17, 2018

Marulićev trg 19, 10000 Zagreb, Croatia 